\title{
Exserohilum turcicum Race Population Distribution in the North Central United States
}

\author{
Japheth D. Weems and Carl A. Bradley, ${ }^{\dagger}$ Department of Crop Sciences, University of Illinois, Urbana, 61801
}

\begin{abstract}
Northern leaf blight (NLB) of corn, caused by Exserohilum turcicum, is a foliar disease common across corn production regions of the world, including those in the north central United States. Previous race population distribution studies identified five physiological races present in the United States, prior to 1995 . For this study, 156 E. turcicum isolates were screened on corn differential lines containing $\mathrm{Htl}, \mathrm{Ht} 2, \mathrm{Ht} 3, \mathrm{Html}$, and $\mathrm{Htn} 1$ resistance genes. Isolates were collected from fields in Iowa, Illinois, Indiana, Minnesota, North Carolina, Ohio, and Wisconsin, which included 143 isolates collected between 2007 and 2014 and 13 isolates collected between 1979 and 1985. Twenty different physiological races were observed based on the symptom response of the differential corn lines. E. turcicum race 0 , 1 , and $1 \mathrm{mn}$ were the most prevalent races, comprising 21,27 , and $13 \%$ of the 156 isolates, respectively. Race populations were diverse within states

and years. Virulence to multiple $\mathrm{Ht}$ resistance genes within individual isolates was observed in $47 \%$ of those tested, with $3 \%$ of the isolates conferring virulence to all $H t$ resistance genes. Virulence to the $H t 1, H t 2, H t 3$, $H t m l$, and $H t n 1$ resistance genes was present in $64,20,18,32$, and $27 \%$ of the E. turcicum isolates, respectively. Virulence to $H t$ resistance genes was fairly evenly distributed across states, in isolates collected after 2008. Virulence to $H t 2, H t 3, H t m l$, and $H t n l$ decreased after 2010. Variations in race population diversity are difficult to explain without knowing the level of selection pressure present in fields, and information regarding $H t$ resistance gene deployment in commercial varieties is not publicly available. Although virulence was observed against all $\mathrm{Ht}$ resistance genes, qualitative $H t$ resistance genes could be used in conjunction with quantitative resistance to increase NLB control.
\end{abstract}

Northern leaf blight (NLB) of corn (Zea mays L.), caused by Exserohilum turcicum (syn. Setosphaeria turcica), is a common disease found in corn-producing areas worldwide (Carson 2016). NLB is a foliar disease that initially presents as green-gray, elliptical lesions that turn necrotic (Carson 2016; Ullstrup and Miles 1957). Under moist field conditions between 18 to $27^{\circ} \mathrm{C}$, lesions expand and coalesce, reducing host photosynthetic potential (Levy and Cohen 1983). Secondary infections occur when conidia, formed on the surface of necrotic lesions, spread to the upper canopy by wind and rain (Carson 1995; Ullstrup and Miles 1957). Disease stress during seed set and fill can result in yield reductions greater than $50 \%$, while potentially increasing the incidence of stalk rots and lodging (Dodd 1980a, b; Fisher et al. 1976; Pedersen and Oldham 1992; Raymundo and Hooker 1981).

Host resistance has been used effectively to manage NLB in the United States through the deployment of qualitative and quantitative resistance. The first qualitative $H t$ resistance gene, designated $H t 1$, was reported in 1963 (Hooker 1963). Unlike susceptible NLB symptoms, the resistance response presents as chlorotic streaking surrounding reduced necrotic lesions with decreased sporulation. The Ht2 and Ht3 genes were reported in 1977 and 1981, respectively, and display similar resistance responses as $\mathrm{Htl}$ but with more necrosis (Hooker 1977, 1981). In 1975, a single gene conferring delayed latent period and decreased lesion number was reported, and it was later designated as the Htnl (syn. HtN) gene (Gevers 1975; Leonard et al. 1989; Welz and Geiger 2000). In 1993, another resistance gene conferring complete resistance to E. turcicum was reported and later designated Html in analogy to Htnl (Robbins and Warren 1993; Welz and Geiger 2000). The $H t 1$ gene often was utilized as the primary form of NLB management in corn breeding lines until virulent $E$. turcicum populations were observed across corn-producing areas of the United States (Ferguson and Carson 2004; Jordan et al. 1983; Lipps and Hite

Present address of J. D. Weems and C. A. Bradley: Department of Plant Pathology, University of Kentucky Research and Education Center, Princeton, 42445 .

${ }^{\dagger}$ Corresponding author: C. A. Bradley; E-mail: carl.bradley@uky.edu

Accepted for publication 27 September 2017.

() 2018 The American Phytopathological Society
1982). The $H t 2, H t 3$, and $H t n 1$ genes have not been heavily utilized in field corn breeding owing to presence of E. turcicum populations virulent against these genes, as well as variations in resistance under different light intensities and temperatures (Ferguson and Carson 2004; Leath et al. 1990; Thakur et al. 1989a, b). Furthermore, a dominant gene, designated $S h t 1$, suppresses expression of $H t 2, H t 3$, and $H t n 1$, which makes backcrossing more difficult (Ceballos and Gracen 1989; Simcox and Bennetzen 1993b). The Html gene also has limited deployment in field corn breeding, and limited E. turcicum race screening has been done using this resistance gene. Quantitative resistance breeding has become the primary method for NLB control owing to the durability of polygenic resistance across environments and E. turcicum races (Carson 1995; Carson and Van Dyke 1994; Jordan et al. 1983; Welz and Geiger 2000).

NLB has increased in prevalence in the United States since 2000 (Mueller et al. 2016; Munkvold et al. 2008; Wise and Mueller 2011). Adoption of reduced-tillage and no-tillage practices, as well as increased hectares in continuous corn, has led to increased corn residue. E. turcicum-infected corn residue generally serves as the primary inoculum for NLB development (Mallowa et al. 2015; Wise and Mueller 2011). Producers tend to select corn hybrids based on high yield potential over those with high disease resistance, which has also led to increased disease severity (Wise and Mueller 2011). This suggests that some high-yield-producing lines may lack adequate quantitative resistance genetics to control NLB in some regions. Single resistance genes can be backcrossed into corn lines fairly quickly relative to breeding for polygenic resistance. The qualitative $\mathrm{Ht}$ genes could increase NLB control if used in conjunction with partial resistance or provide protection while quantitative resistance is improved in high-yield-producing lines. Lipps et al. (1997) reported that crosses of lines containing $H t$ genes and lines with moderate partial resistance controlled NLB better than crosses of the same lines without $\mathrm{Ht}$ genes and lines with moderate partial resistance when inoculated with $E$. turcicum race 0 (avirulent to all $H t$ genes). In addition, Pataky et al. (1986) reported that qualitative resistance genes and high partial resistance were equally effective in limiting spread and development of NLB in the presence of a race avirulent against $H t$ genes.

To determine if any of the $H t$ genes could be widely deployed to aid in NLB control, the distribution of E. turcicum race populations in corn-producing regions must be assessed. E. turcicum races are determined by inoculating differential corn lines containing the individual $\mathrm{Ht}$ genes and assessing host resistance responses (Berguist and Masias 1974). Physiological races are designated based on virulence 
to host $H t$ gene(s). For example, race 1 of E. turcicum is virulent against the $H t 1$ gene; race $23 \mathrm{n}$ is virulent against the $H t 2, H t 3$, and $H t n l$ genes; and race 0 is avirulent against all of the $H t$ genes (Leonard et al. 1989). Previous studies, conducted with various isolates collected prior to 1995 , showed that five races occur in the United States. Races 0 and 1 were observed to be dominant, and races $23,2 \mathrm{n}$, and $23 \mathrm{n}$ occurred at much lower frequencies (Ferguson and Carson 2004, 2007; Moghaddam and Pataky 1994; Windes and Pedersen 1991). Little is known about the present E. turcicum race population distribution in the central United States or the presence of selection pressure. It is widely believed that $\mathrm{Ht}$ genes are not being intentionally deployed in private, commercially developed hybrids; however, that information is not publicly available (Carson 1995; Carson and Van Dyke 1994; Jordan et al. 1983; Welz and Geiger 2000). The purpose of this study was to determine the race population distribution of E. turcicum present in the north central United States.

\section{Materials and Methods}

Isolate collection. The E. turcicum collection consisted of 156 isolates obtained from corn. Thirteen isolates collected prior to 1986 were from a collection originally compiled by M. Carson and later curated by P. Balint-Kurti (United States Department of AgricultureAgricultural Research Service, Raleigh, NC) (Ferguson and Carson 2004, 2007). In addition to these 13 "historical" isolates, isolates from corn leaf samples from Illinois, Indiana, Iowa, Ohio, and Wisconsin were collected from 2007 to 2014. Either leaf samples or isolate cultures collected from 2009 to 2014 from states other than Illinois were provided by A. Robertson (Iowa State University, Ames, IA), P. Esker (University of Wisconsin, Madison, WI), P. Paul (Ohio State University, Wooster, OH), and K. Wise (Purdue University, West Lafayette, IN). NLB symptomatic leaves were received and placed in humidity chambers (sealed plastic bags containing a damp paper towel) to induce sporulation. Conidia were rinsed off the leaf surface with 200 to $500 \mu$ l of water, and the conidial suspension was spread onto Petri dishes containing potato dextrose agar (PDA) (Fisher Scientific, Pittsburgh, PA) amended with rifampicin ( $25 \mathrm{mg} /$ liter) (Fisher Scientific) to inhibit bacterial growth. Conidia were allowed to germinate, and single germinated E. turcicum conidia were collected and transferred to new PDA the following day. Isolates were allowed to grow at 20 to $25^{\circ} \mathrm{C}$ with 12-h light/dark conditions for 7 to 14 days before mycelia samples were cut from plates and placed in 1.5-ml tubes containing $850 \mu \mathrm{l}$ of $15 \%$ glycerol solution. Tubes were placed in a $-80^{\circ} \mathrm{C}$ freezer for long-term storage until isolates were screened for race type. The final collection contained isolates collected between 1979 and 2014 from Illinois, Indiana, Iowa, Minnesota, North Carolina, Ohio, and Wisconsin (Table 1).

Race determinations. To determine race, virulence was assessed on differential corn lines containing Ht1, Ht2, Ht3, Html, or Htnl qualitative resistance genes or no $H t$ qualitative resistance gene. Unfortunately, limitations in the quantity of seed of lines that contained Htl, Html, or $H t n 1$ required the use of multiple lines to test all isolates. The corn lines containing the $H t$ resistance genes were A619 (no Ht genes), A619Ht1, B37Ht1, A619Ht2, A619Ht3, H102Html, H117Html, MayorbelaHtml, Mayorbela(R)C3Htm1, A509Htn1, A632Htn1, B37Htn1, FRSHtn1, MLSHtn1, and MRSHtn1. The majority of the seed for the A619 near-isogenic lines, H102Html, A632Htnl, and A509Htnl, used for the differential screening was provided by K. Jindal (Agriculture and Agri-Food Canada, Ottawa, ON) and A. Tenuta (Ontario Ministry of Agriculture, Food and Rural Affairs, Ridgetown, ON). A small portion of seed for the A619 lines and all of the seed for the B37 near-isogenic lines came from a collection at the University of Illinois (Urbana, IL). The remaining $\mathrm{Html}$ and $\mathrm{Htnl}$ screening lines were procured from the U.S. National Plant Germplasm System (United States Department of Agriculture-Agricultural Research Service, North Central Region Plant Introduction System, Ames, IA). Polyethylene pots $(30.2 \mathrm{~cm}$ wide $\times$ $27.9 \mathrm{~cm}$ tall, C2000, Nursery Supplies, Chambersburg, PA) were filled with a 1:1:1 (soil/peat/perlite) steam-pasteurized soil mixture. All pots were planted with 18 seeds, including 3 seeds of each $H t$ resistance gene type (Htl, Ht2, Ht3, Htm l, and Htn l) and 3 seeds of the A619 with no
$\mathrm{Ht}$ genes to serve as a positive control to verify successful inoculation and disease development. All plants in each pot were inoculated with a single E. turcicum isolate, with individual plants containing the $\mathrm{Ht}$ genes serving as a replication. Isolate screens were not replicated over time to allow for a greater number of isolates to be evaluated. Plants were watered as needed and fertilized with Osmocote Classic 13-13-13 (N-P-K) controlled release fertilizer (Scott's, Marysville, $\mathrm{OH}$ ) to maintain plant growth. The greenhouse was maintained at $21 \pm 3^{\circ} \mathrm{C}$ daytime and $18 \pm 3^{\circ} \mathrm{C}$ nighttime temperatures. Plants were grown under $1,000-\mathrm{W}$ high-pressure sodium bulbs at 25 to $50 \mathrm{klux}$ ( 325 to $650 \mu \mathrm{E} / \mathrm{m}^{2} \cdot \mathrm{s}$ ) with 15 -h daytime and 9-h nighttime. Greenhouse temperature and light intensity were consistent with those used by Leonard et al. (1989) and Ferguson and Carson (2004), because virulence to $H t 1, H t 2$, and $H t 3$ can be affected by varying temperature and light intensity (Leath et al. 1990; Thakur et al. 1989a, b). Plants were inoculated at the four-leaf growth stage.

E. turcicum isolates were grown on lactose casein agar (Tuite 1969). Cultures were maintained at 20 to $25^{\circ} \mathrm{C}$ under a 12-h light and dark regime for 7 to 14 days to promote sporulation (Ferguson and Carson 2004). Plugs were cut from the sporulating cultures, placed in $1.5-\mathrm{ml}$ tubes containing $800 \mu \mathrm{l}$ of water, and vortexed to dislodge conidia. Conidial suspensions were quantified with a hemocytometer and diluted with water containing Tween 20 (10 $\mu 1 /$ liter) to 1,000 conidia/ml (Ferguson and Carson 2004). Plants were inoculated in the whorl with $150 \mu \mathrm{l}$ of the conidial suspension using a pipette. To promote infection, plants were placed in a humidity chamber in the greenhouse for 20 to $24 \mathrm{~h}$ following inoculation. The humidity chamber consisted of a clear plastic tent constructed in the greenhouse with two humidifiers (707 atomizing humidifier, Trion Air Purification Systems, Sanford, NC) that maintained relative humidity near $100 \%$.

Plants were evaluated for symptoms of infection 14 and 21 days after inoculation. An isolate known to be avirulent to all $\mathrm{Ht}$ genes (race 0 ) as well as an isolate with known virulence to the $H t 1$ gene were included in the initial screen to evaluate methods and confirm susceptible and resistant responses. Across all corn lines, susceptible host responses caused by virulent $E$. turcicum isolates initially appeared as gray-green elliptical lesions in the first week, turning necrotic by the 14-day evaluation and continuing to increase in size by the 21-day evaluation. Host resistant responses (avirulence) provided by Htl, $H t 2$, and $H t 3$ appeared as chlorotic streaking surrounding reduced necrotic lesions. Host resistant responses provided by $\mathrm{Ht} 2$ and $\mathrm{Ht} 3$ usually displayed more necrosis than $H t 1$. The host resistance response provided by Htm 1 appeared as slight necrotic flecking at the point of infection, with minimal necrotic lesions. The Htnl host resistance response delayed lesion development past the 14-day evaluation and reduced lesion size at 21 days when compared with the control, if symptoms developed at all. If the appropriate $H t$ host resistance response was observed on any of the plants containing the $\mathrm{Ht}$ gene, the isolate was considered avirulent against that gene. Races were assigned based on plant resistance responses following the race scheme outlined by Leonard et al. (1989).

The frequency of plant $\mathrm{Ht}$ resistance responses for each $\mathrm{Ht}$ genotype (number of plants demonstrating resistant phenotype: three differential plant replicants) were determined to evaluate the consistency and reliability of avirulent observations. The Habgood-Gilmour spreadsheet (HiGiS) was used to summarize isolate race and virulence data for individual states and years, as well as all isolates combined (Herrmann et al. 1999). Race distribution, frequency distributions of isolate virulence to $H t$ resistance genes, isolate virulence complexity (the number of $\mathrm{Ht}$ resistance genes with which an isolate has a susceptible interaction), and three commonly used diversity indices (the simple, Gleason, and Shannon indices) were calculated and described for states and years. The simple index $\left(I_{s}\right)$ is the ratio of phenotypic races to total isolates sampled: $I_{s}=r / N$, where $r$ is the number of races observed and $N$ is the number of isolates sampled. The Gleason index $\left(I_{g}\right)$, although similar to the simple index, is less sensitive to sample size: $I_{g}=$ $(r-1) / \ln (N)$, where $r$ is the number of races and $N$ is the number of isolates sampled. The Shannon index $\left(I_{w}\right)$ takes into account the number of races as well as the evenness of race distribution: $I_{w}=-\sum p_{i} \ln \left(p_{i}\right)$, where $p_{i}$ is the frequency of the $i$ th phenotypic race. 
Diversity indices were calculated in the HiGiS program using these formulas presented by Groth and Roelfs (1987).

\section{Results}

When inoculated with a virulent isolate, typical NLB leaf lesions occurred within 14 days and expanded in size 21 days following inoculation in susceptible plants across all genetic backgrounds and $\mathrm{Ht}$ genes. The phenotypic resistance responses of the differential lines were consistent with the expected results for the known race 0 and $H t l$ virulent isolates. The avirulent race 0 isolate elicited resistant responses from all differential lines containing $\mathrm{Ht}$ genes, whereas the line virulent to $\mathrm{Ht} 1$ resulted in susceptible disease development in the Htl differential line. Individual isolate inoculations were considered successful and screening data collected when disease symptoms were observed on the susceptible A619 plants containing no $H t$ genes. Resistant responses were not always observed in all $H t$ differential plants when inoculated with an avirulent isolate (Table 2). When Ht1 differential lines were inoculated with an avirulent isolate, resistant plant responses were observed in all three plants (3:3) $56 \%$ of the time, 2 of 3 plants (2:3) $30 \%$ of the time, and 1 of 3 plants (1:3) $14 \%$ of the time. Similar ratio frequencies were observed in $\mathrm{Ht} 2$ and $\mathrm{Ht} 3$ differential lines. The $\mathrm{Htm} 1$ resistance response ratio frequencies in the presence of avirulent isolates were 3:3 plants $30 \%, 2: 3$ plants $54 \%$, and 1:3 plants $17 \%$ in the avirulent isolate screens. The Htnl resistance response ratio frequencies in the presence of avirulent isolates were $3: 3$ plants $36 \%, 2: 3$ plants $31 \%$, and $1: 3$ plants $33 \%$ in the avirulent isolate screens.

Twenty races of $E$. turcicum were observed when the isolates were tested on the corn differential lines containing the various $\mathrm{Ht}$ resistance genes (Table 1). Races observed were not consistent across years. Race 0 (avirulent against all $H t$ genes) was detected in $50 \%$

Table 1. Origin by state, county, and year of Exserohilum turcicum collection, number of isolates, and race determined by differential screening lines containing $H t 1, H t 2, H t 3, H t m 1$, and Htn 1

\begin{tabular}{|c|c|c|c|c|}
\hline State & County & Year & No. of isolates & Races $^{\mathbf{a}}$ \\
\hline \multirow[t]{3}{*}{ Iowa } & Story & 2009 & 4 & $1(1), 12(1), 1 \mathrm{mn}(1), \mathrm{m}(1)$ \\
\hline & & 2010 & 8 & $123(2), 123 \mathrm{mn}(1), 1 \mathrm{~m}(1), 1 \mathrm{mn}(3), \mathrm{m}(1)$ \\
\hline & Washington & 2011 & 21 & $0(3), 1(13), 123(1), 13(1), 123 \mathrm{~m}(1), 1 \mathrm{~m}(2)$ \\
\hline \multirow[t]{28}{*}{ Illinois } & Champaign & 2007 & 2 & $23(1), 23 \mathrm{~m}(1)$ \\
\hline & & 2009 & 1 & $0(1)$ \\
\hline & & 2010 & 4 & $1 \mathrm{~m}(2), 2(1), 23(1)$ \\
\hline & & 2011 & 1 & $1 \mathrm{mn}(1)$ \\
\hline & & 2012 & 2 & $1(1), \ln (1)$ \\
\hline & & 2014 & 1 & $1(1)$ \\
\hline & DeKalb & 2010 & 12 & $1(3), 123(2), 123 \mathrm{mn}(1), 1 \mathrm{mn}(4), 23 \mathrm{mn}(2)$ \\
\hline & & 2012 & 5 & $1(2), 123 \mathrm{~m}(1), 13(1), 1 \mathrm{n}(1)$ \\
\hline & & 2014 & 1 & $1(1)$ \\
\hline & Ford & 2009 & 3 & $1(1), 123 \mathrm{~m}(1), 1 \mathrm{n}(1)$ \\
\hline & & 2011 & 3 & $1(1), 1 \mathrm{mn}(2)$ \\
\hline & Gallatin & 2014 & 1 & $0(1)$ \\
\hline & Iroquois & 1979 & 2 & $0(2)$ \\
\hline & Johnson & 2010 & 1 & $0(1)$ \\
\hline & Kane & 2010 & 2 & $12 \mathrm{mn}(1), 23 \mathrm{n}(1)$ \\
\hline & Mclean & 2011 & 1 & $0(1)$ \\
\hline & Piatt & 2009 & 3 & $12(2), 2 \mathrm{mn}(1)$ \\
\hline & & 2011 & 3 & $0(2), \mathrm{n}(1)$ \\
\hline & & 2012 & 3 & $0(1), 1 \mathrm{~m}(1), 1 \mathrm{mn}(1)$ \\
\hline & Pike & 2010 & 1 & $0(1)$ \\
\hline & Pope & 2014 & 1 & $0(1)$ \\
\hline & Saline & 2014 & 1 & $0(1)$ \\
\hline & Sangamon & 2010 & 5 & $0(2), 1(2), 1 \mathrm{n}(1)$ \\
\hline & & 2014 & 1 & $0(1)$ \\
\hline & St. Clair & 2009 & 3 & $23(3)$ \\
\hline & Vermilion & 1981 & 2 & $\mathrm{n}(2)$ \\
\hline & Warren & 2012 & 2 & $1(2)$ \\
\hline & Woodford & 1981 & 1 & $0(1)$ \\
\hline \multirow[t]{7}{*}{ Indiana } & Clark & 1980 & 2 & $0(1), 23(1)$ \\
\hline & Henry & 2014 & 3 & $1(2), 1 \mathrm{~m}(1)$ \\
\hline & Knox & 2014 & 1 & $0(1)$ \\
\hline & North IN ${ }^{\mathrm{b}}$ & 2012 & 1 & $1(1)$ \\
\hline & Tippecanoe & 2011 & 3 & $0(2), \ln (1)$ \\
\hline & & 2013 & 1 & $1(1)$ \\
\hline & Wabash & 2014 & 2 & $0(1), 123 \mathrm{~m}(1)$ \\
\hline Minnesota & Swift & 1981 & 1 & $0(1)$ \\
\hline \multirow[t]{2}{*}{ North Carolina } & Wilkes & 1985 & 3 & $0(1), 23 \mathrm{~m}(1), 23 \mathrm{mn}(1)$ \\
\hline & $\mathrm{NA}^{\mathrm{c}}$ & 1985 & 1 & $23(1)$ \\
\hline \multirow[t]{4}{*}{ Ohio } & Clark & 2009 & 4 & $1(1), 1 \mathrm{mn}(1), \ln (2)$ \\
\hline & & 2010 & 9 & $0(2), 1 \mathrm{~m}(1), 1 \mathrm{mn}(3), \mathrm{mn}(2), \mathrm{n}(1)$ \\
\hline & Wayne & 1980 & 1 & $0(1)$ \\
\hline & & 2011 & 18 & $0(3), 1(9), 123 \mathrm{mn}(1), 1 \mathrm{~m}(1), 1 \mathrm{mn}(2), 1 \mathrm{n}(1), \mathrm{m}(1)$ \\
\hline \multirow[t]{2}{*}{ Wisconsin } & Grant & 2009 & 3 & $1 \mathrm{mn}(3)$ \\
\hline & & 2010 & 2 & $13(1), 1 \mathrm{~m}(1)$ \\
\hline
\end{tabular}

${ }^{\mathrm{a}}$ The number of isolates belonging to a race are in parenthesis following the race nomenclature.

${ }^{\mathrm{b}}$ The county where the isolate collected was not recorded, but the general location was northern Indiana.

${ }^{\mathrm{c}}$ The location where the isolate was collected is not available (NA). 
of the counties sampled in Iowa, $65 \%$ of the counties sampled in Illinois, $80 \%$ of the counties sampled in Indiana and Minnesota, $50 \%$ of the counties sampled in North Carolina, and $100 \%$ of the counties sampled in Ohio. Races containing virulence to $H t 1$ were detected in $100 \%$ of the counties sampled in Iowa, $41 \%$ of the counties sampled in Illinois, $80 \%$ of the counties sampled in Indiana, none of the counties sampled in Minnesota or North Carolina, and $100 \%$ of the counties sampled in Ohio and Wisconsin. Races with virulence to $\mathrm{Ht} 2$ were identified in $100 \%$ of the counties sampled in Iowa, 35\% of the counties sampled in Illinois, $40 \%$ of the counties sampled in Indiana, $100 \%$ of counties sampled in North Carolina, and $50 \%$ of the counties sampled in Ohio. Virulence to Ht2 and Ht3 were observed in all the same locations, except Piatt County, Illinois, and Grant County, Wisconsin. Virulence to $\mathrm{Html}$ was detected in $100 \%$ of the counties sampled in Iowa, $29 \%$ of the counties sampled in Illinois, $40 \%$ of the counties sampled in Indiana, $50 \%$ of the counties sampled in North Carolina, and $100 \%$ of the counties sampled in both Ohio and Wisconsin. Virulence to Htnl was detected in $50 \%$ of the counties sampled in Iowa, $41 \%$ of the counties sampled in Illinois, $20 \%$ of the counties sampled in Indiana, one location in North Carolina, $100 \%$ of the counties sampled in Ohio, and $50 \%$ of the counties sampled in Wisconsin. In counties where samples were collected over multiple years, virulence profiles were not the same each year.

The E. turcicum population was fairly complex, with virulence to multiple resistance genes observed in $47 \%$ of the isolates, which led to the high number of observed races (Fig. 1). Isolates with virulence to two or three $\mathrm{Ht}$ genes were observed approximately as often as race 0 in this population. Only $7 \%$ of the screened isolates conferred resistance to more than three $H t$ genes. Ten races were observed in Iowa, 18 races in Illinois, 6 races in Indiana, 1 race in Minnesota,

Table 2. Resistant plant response frequency ratios for the three plants of each $\mathrm{Ht}$ resistance genotype inoculated with the individual isolates

\begin{tabular}{lcccc}
\hline & \multicolumn{3}{c}{$\begin{array}{c}\text { Frequency of resistant } \\
\text { plant response ratio }\end{array}$} & \\
\cline { 2 - 4 } $\boldsymbol{H} \boldsymbol{t}$ gene & $\mathbf{1 / 3}^{\mathbf{a}}$ & $\mathbf{2 / 3}^{\mathbf{a}}$ & $\mathbf{3 / 3}^{\mathbf{a}}$ & Total avirulent isolates \\
\hline $\mathrm{Ht1}$ & $8^{\mathrm{b}}$ & 17 & 32 & $57^{\mathrm{c}}$ \\
$\mathrm{Ht2}$ & 16 & 38 & 72 & 126 \\
$\mathrm{Ht3}$ & 17 & 43 & 72 & 132 \\
$\mathrm{Htm1}$ & 18 & 58 & 32 & 108 \\
$\mathrm{Htn1}$ & 37 & 35 & 40 & 112 \\
\hline
\end{tabular}

${ }^{a}$ Number of plants out of three plants with resistant phenotype. $1 / 3=1$ out of 3 plants, $2 / 3=2$ out of 3 plants, and $3 / 3=3$ out of 3 plants.

${ }^{\mathrm{b}}$ The observed number of the $H t$ resistant plant responses.

${ }^{c}$ The number of isolates avirulent to the specific $H t$ genotype.
4 races in North Carolina, 9 races in Ohio, and 3 races in Wisconsin. Race 1 , race 0 , and race $1 \mathrm{mn}$ were the most commonly observed races and comprised 27,21 , and $13 \%$ of the total isolates tested, respectively (Table 3 ). Race 1 was the predominant race in Iowa and Ohio, whereas race 0 was predominant in Illinois, Indiana, and Minnesota (although only one isolate was tested from Minnesota). Races were evenly distributed among isolates in North Carolina, and $1 \mathrm{mn}$ was the predominant race in Wisconsin.

When race diversity indices were calculated for each state, Ohio had the greatest simple diversity (the proportion of races to number of isolates collected), whereas Illinois had the highest Gleason (indicating race richness) and Shannon (indicating evenness of race distribution within a state) indices of diversity (Table 4). The different indices of diversity aid to describe the race population distribution between states, but they are affected by variations in the number and distribution of fields sampled and isolates collected within each state and should be considered cautiously. Illinois had the greatest number of isolates collected from more fields than any other state. Generally, sampling more fields and testing more isolates from within a state resulted in the observation of more races. The simple diversity was greatest in 2007 , whereas the greatest Gleason (indicating race richness) and Shannon (indicating evenness of race distribution within a state) indices of diversity values were observed in 2010 (Table 4). Similar to the state comparisons, differences in indices of diversity are affected by the number and distribution of fields sampled and isolates collected within years. The greatest number of states and fields were represented in 2010.

The frequency of virulence to the specific $\mathrm{Ht}$ genes was also examined across states (Table 5). In Iowa, Illinois, Indiana, Ohio, and Wisconsin, virulence to $H t l$ was present in greater than $50 \%$ of the isolates. Htnl virulence was observed in all states, except Minnesota, and varied in its frequency. Html virulence was present in all states, except Minnesota, at levels similar to or greater than $\mathrm{Ht} 2, \mathrm{Ht} 3$, and $H t n 1$. Isolates avirulent to all $H t$ genes (race 0) were present in all states but often at a low frequency. Of the isolates tested, $21 \%$ were avirulent to all $H t$ genes, $64 \%$ were virulent to $H t 1,20 \%$ were virulent to $H t 2,18 \%$ were virulent to $H t 3,32 \%$ were virulent to $H t n 1$, and $28 \%$ were virulent to $\mathrm{Html}$.

Similarly, when examining temporal race distribution, the number of races observed within years tended to increase with the number of isolates tested (Table 6). Five races were observed for isolates collected between 1979 and 1985, 2 races in 2007, 9 races in 2009, 16 races in 2010, 11 races in 2011, 7 races in 2012, 1 race in 2013, and 4 races in 2014. Race 0 was the most prevalent among isolates collected between 1979 and 1985, as well as isolates collected in 2014. Race $1 \mathrm{mn}$ was observed in greater frequency than any other race in 2009 and 2010. In 2011, 2012, and 2013 (only one isolate was tested in 2013), race 1 was present in the highest number of isolates.

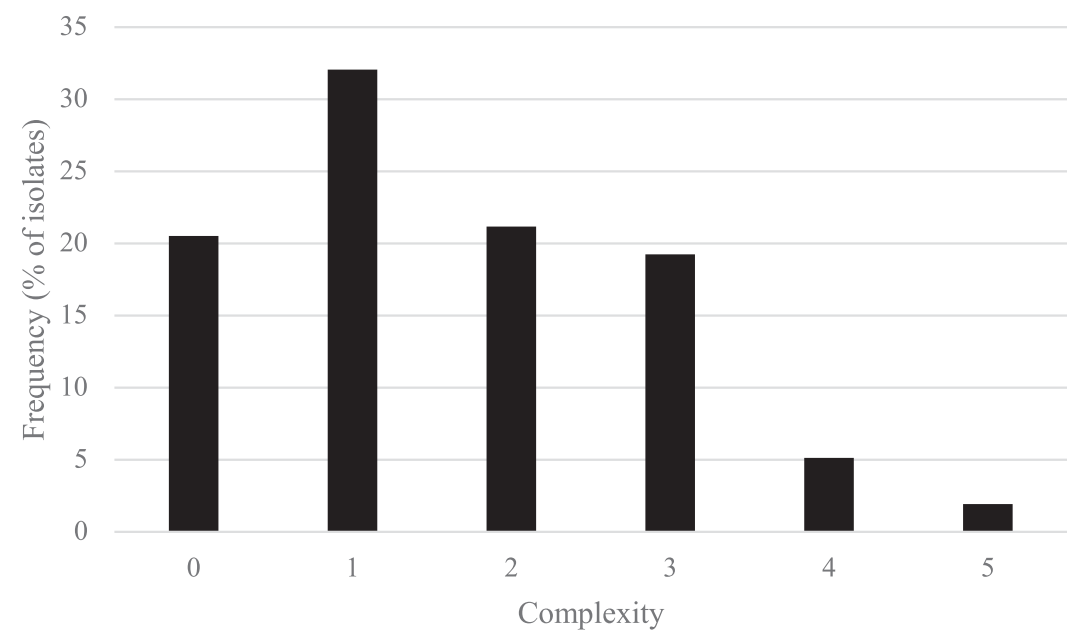

Fig. 1. The complexity of Exserohilum turcicum races collected in a seven-state survey between 1979 and 2014, denoted by the number of differential lines with which a specific isolate caused a susceptible response. 
A shift in virulence to $H t$ genes was observed among years (Table 7). Greater than half of the isolates collected between 1979 and 1985 were race 0 , inducing resistance responses on hosts containing any of the $\mathrm{Ht}$ genes. No virulence to $\mathrm{Htl}$ was detected in isolates collected prior to 2009 ; however, $H t l$ virulence was observed in the majority of isolates collected in 2009 and subsequent years. After 2010, the frequency of $\mathrm{Ht} 2$ and $\mathrm{Ht} 3$ virulence decreased compared with isolates collected previously. A similar reduction was observed in $H t n 1$ and $H t m l$ virulence after 2010.

\section{Discussion}

In this race survey, a much greater number of races were observed than previously reported in the United States. In previous reports, the commonly reported races detected in U.S. fields were $0,1,23,2 \mathrm{n}$, and 23n, with race 0 and 1 being the most frequent (Moghaddam and Pataky 1994; Simcox et al. 1993; Windes and Pedersen 1991). In the isolates tested here, 20 races were observed at fairly equal frequencies, with the exception of races 0,1 , and $1 \mathrm{mn}$, which were more common. The increased number of races observed resembles more recent results from other corn-producing regions, such as Europe, Africa, and China, where races have been reported to be more diverse (Dong et al. 2008; Muiru et al. 2010). It is possible that additional races have developed over time in the United States, because previous studies focused on isolates collected prior to 1995 (Ferguson and Carson 2004, 2007; Thakur et al. 1989a, b; Windes and Pedersen 1991). Another reason more races were identified in this study is the inclusion of lines containing the Html resistance gene in the differential test, whereas previous race population studies in the United

Table 3. Frequency of Exserohilum turcicum isolates of each race found in states

\begin{tabular}{|c|c|c|c|c|c|c|c|c|}
\hline \multirow[b]{2}{*}{ Race } & \multicolumn{7}{|c|}{ E. turcicum race distribution by state $(\%)$} & \multirow[b]{2}{*}{ Isolates per race $(\%)$} \\
\hline & Iowa & Illinois & Indiana & Minnesota & North Carolina & Ohio & Wisconsin & \\
\hline 0 & 9 & 24 & 38 & 100 & 25 & 19 & $\ldots$ & 20.5 \\
\hline 1 & 42 & 21 & 31 & $\ldots$ & $\ldots$ & 31 & $\ldots$ & 26.9 \\
\hline 12 & 3 & 3 & $\ldots$ & $\ldots$ & $\ldots$ & $\ldots$ & $\ldots$ & 1.9 \\
\hline 13 & 3 & 1 & $\ldots$ & $\ldots$ & $\ldots$ & $\ldots$ & 20 & 1.9 \\
\hline 123 & 9 & 3 & $\ldots$ & $\ldots$ & $\ldots$ & $\ldots$ & $\ldots$ & 3.2 \\
\hline $123 \mathrm{~m}$ & 3 & 3 & 8 & $\ldots$ & $\ldots$ & $\ldots$ & $\ldots$ & 2.6 \\
\hline $12 \mathrm{mn}$ & $\ldots$ & 1 & $\ldots$ & $\ldots$ & $\ldots$ & $\ldots$ & $\ldots$ & 0.6 \\
\hline $123 \mathrm{mn}$ & 3 & 1 & $\ldots$ & $\ldots$ & $\ldots$ & 3 & $\ldots$ & 1.9 \\
\hline $1 \mathrm{~m}$ & 9 & 4 & 8 & $\ldots$ & $\ldots$ & 6 & 20 & 6.4 \\
\hline $1 \mathrm{mn}$ & 12 & 12 & $\ldots$ & $\ldots$ & $\ldots$ & 19 & 60 & 13.5 \\
\hline 1n & $\ldots$ & 6 & 8 & $\ldots$ & $\ldots$ & 9 & $\ldots$ & 5.1 \\
\hline 2 & $\ldots$ & 1 & $\ldots$ & $\ldots$ & $\ldots$ & $\ldots$ & $\ldots$ & 0.6 \\
\hline 23 & $\ldots$ & 7 & 8 & $\ldots$ & 25 & $\ldots$ & $\ldots$ & 4.5 \\
\hline $23 m$ & $\ldots$ & 1 & $\ldots$ & $\ldots$ & 25 & $\ldots$ & $\ldots$ & 1.3 \\
\hline $2 \mathrm{mn}$ & $\ldots$ & 1 & $\ldots$ & $\ldots$ & $\ldots$ & $\ldots$ & $\ldots$ & 0.6 \\
\hline $23 \mathrm{mn}$ & $\ldots$ & 3 & $\ldots$ & $\ldots$ & 25 & $\ldots$ & $\ldots$ & 1.9 \\
\hline $23 n$ & $\ldots$ & 1 & $\ldots$ & $\ldots$ & $\ldots$ & $\ldots$ & $\ldots$ & 0.6 \\
\hline $\mathrm{m}$ & 6 & $\ldots$ & $\ldots$ & $\ldots$ & $\ldots$ & 3 & $\ldots$ & 1.9 \\
\hline $\mathrm{mn}$ & $\ldots$ & $\ldots$ & $\ldots$ & $\ldots$ & $\ldots$ & 6 & $\ldots$ & 1.3 \\
\hline $\mathrm{n}$ & $\ldots$ & 4 & $\ldots$ & $\ldots$ & $\ldots$ & 3 & $\ldots$ & 2.6 \\
\hline Total no. of isolates $\mathrm{a}^{\mathrm{a}}$ & 33 & 68 & 13 & 1 & 4 & 32 & 5 & $156^{\mathrm{b}}$ \\
\hline
\end{tabular}

${ }^{a}$ The total number of isolates evaluated for race from each state.

$\mathrm{b}$ The total number of isolates evaluated for race.

Table 4. Number of counties sampled, isolates collected, races identified, and calculated diversity indices for Exserohilum turcicum populations across states and years

\begin{tabular}{|c|c|c|c|c|c|c|c|}
\hline \multirow[b]{2}{*}{ State } & \multirow[b]{2}{*}{ Year } & \multirow[b]{2}{*}{ No. of counties } & \multirow[b]{2}{*}{ No. of isolates } & \multirow[b]{2}{*}{ No. of races ${ }^{b}$} & \multicolumn{3}{|c|}{ Indices of diversity ${ }^{a}$} \\
\hline & & & & & Simple & Gleason & Shannon \\
\hline Iowa (IA) & 2009, 2010, 2011 & 2 & 33 & 10 & 0.30 & 2.57 & 1.87 \\
\hline Illinois (IL) & 1979, 1981, 2007, 2009, 2010, 2011, 2012, 2014 & 17 & 68 & 18 & 0.26 & 4.03 & 2.40 \\
\hline Indiana (IN) & $1980,2011,2012,2013,2014$ & $6^{\mathrm{c}}$ & 13 & 6 & 0.46 & 1.95 & 1.52 \\
\hline Minnesota (MN) & 1981 & 1 & 1 & 1 & $\ldots$ & $\ldots$ & $\ldots$ \\
\hline North Carolina (NC) & 1985 & $2^{\mathrm{c}}$ & 4 & 4 & 1.00 & 2.16 & 1.39 \\
\hline Ohio $(\mathrm{OH})$ & 2009, 2010, 2011 & 2 & 32 & 9 & 0.28 & 2.31 & 1.88 \\
\hline Wisconsin (WI) & 2009,2010 & 1 & 5 & 3 & 0.60 & 1.24 & 0.95 \\
\hline $\mathrm{IL}, \mathrm{IN}, \mathrm{MN}, \mathrm{NC}, \mathrm{OH}$ & $1979-1985$ & 8 & 13 & 5 & 0.38 & 1.56 & 1.30 \\
\hline IL & 2007 & 1 & 2 & 2 & 1.00 & 1.44 & 0.69 \\
\hline IA, IL, OH, WI & 2009 & 7 & 21 & 9 & 0.43 & 2.63 & 2.03 \\
\hline IA, IL, OH, WI & 2010 & 9 & 44 & 16 & 0.36 & 3.96 & 2.43 \\
\hline $\mathrm{IA}, \mathrm{IL}, \mathrm{IN}, \mathrm{OH}$ & 2011 & 7 & 50 & 11 & 0.22 & 2.56 & 1.69 \\
\hline IL & 2012 & 5 & 13 & 7 & 0.54 & 2.34 & 1.63 \\
\hline IN & 2013 & 1 & 1 & 1 & $\ldots$ & $\ldots$ & $\ldots$ \\
\hline IL, IN & 2014 & 9 & 12 & 4 & 0.33 & 1.21 & 1.13 \\
\hline Total & & $31^{\mathrm{c}}$ & 156 & 20 & 0.13 & 3.76 & 2.34 \\
\hline
\end{tabular}


States included Ht1, Ht2, Ht3, and Htn1 (Ferguson and Carson 2004; Thakur et al. 1989a; Windes and Pedersen 1991). To our knowledge, this is first study to include the Html gene in a race screen of a U.S. E. turcicum population, which allowed another level of race separation, increasing the number of races observed. Variations in number of races observed among studies could be the result of the screening method. Leath et al. (1990) concluded it was difficult to consistently determine race, even in the greenhouse, owing to the effect that changes in temperature and light intensity had on E. turcicum virulence to the $H t$ resistance genes. Environmental effects may explain some of the inconsistencies in $\mathrm{Ht}$ plant resistance responses observed in this study. Furthermore, potential contamination of the source seed containing the various $\mathrm{Ht}$ resistance genes is a concern when using differential lines (Simcox and Bennetzen 1993a). Although the differential lines were inoculated with a known race 0 to verify resistance responses, seeds without $H t$ resistance genes may have been present.

There was a high diversity of races observed within regions and years. Multiple races could be observed within counties and within fields. Some inconsistency among states and years is likely to be the result of isolates collected from different fields within counties, variations in corn hybrids sampled, and the relatively limited sample size within states and years. Although these variations in sampling make it difficult to draw clear comparisons between population diversity across states and years, the high race diversity within states and years is important. This diversity of races is somewhat unexpected in a population considered highly clonal in the north central United States (Carson 2016; Ferguson and Carson 2004; Welz and Geiger 2000). Ferguson and Carson (2004) did report high genetic diversity with approximately equal gametic phase equilibrium and equal proportions of mating types in Indiana, Kentucky, Ohio, and North Carolina, which suggested that sexual recombination was occurring in those regions. Furthermore, they concluded that E. turcicum inoculum may travel long distances, which could cause new race introductions and race diversity in fields. As race complexity (virulence to multiple $H t$ genes) increased, frequency decreased, suggesting possible fitness penalties associated with virulence genes. The diversity of races in this collection does suggest a genetically diverse population, possibly owing to sexual recombination or mutation, and the presence of some selection.

Races 0 and 1 remained the most frequently observed and were widely distributed across states, similar to earlier studies (Ferguson and Carson 2004; Jordan et al. 1983). Races 1m, 1mn, and 1n were the second most frequently observed. The wide distribution of race 0 could be the result of reduced use of $\mathrm{Ht}$ resistance genes in breeding programs, which shifted to the use of quantitative resistance to control NLB after virulence to $H t$ genes was observed in the 1970s and 1980s (Welz and Geiger 2000). The Htl gene, and to a lesser extent the Htnl gene, were commonly incorporated in commercial lines until virulence was readily observed (Leonard 1993; Raymundo and Hooker 1982; Turner and Johnson 1980). In this study, several races virulent to $H t l$ and $H t n l$ were identified in regions traditionally used

Table 5. Frequency of Exserohilum turcicum isolates virulent to the $H t$ resistance genes within and across states

\begin{tabular}{|c|c|c|c|c|c|c|c|}
\hline \multirow[b]{2}{*}{ State } & \multicolumn{6}{|c|}{ Virulent isolates for each $\mathrm{Ht}$ gene $(\%)^{\mathrm{a}}$} & \multirow[b]{2}{*}{ No. of isolates per state } \\
\hline & Avirulent & Ht1 & $H t 2$ & $H+3$ & Htm1 & Htn1 & \\
\hline Iowa & 9 & 85 & 18 & 18 & 33 & 15 & 33 \\
\hline Illinois & 24 & 56 & 28 & 22 & 28 & 31 & 68 \\
\hline Indiana & 38 & 54 & 15 & 15 & 15 & 8 & 13 \\
\hline Minnesota & 100 & 0 & 0 & 0 & 0 & 0 & 1 \\
\hline North Carolina & 25 & 0 & 75 & 75 & 50 & 25 & 4 \\
\hline Ohio & 19 & 69 & 3 & 3 & 38 & 41 & 32 \\
\hline Wisconsin & 0 & 100 & 0 & 20 & 80 & 60 & 5 \\
\hline All states & 21 & 64 & 20 & 18 & 32 & 28 & $156^{\mathrm{b}}$ \\
\hline
\end{tabular}

a Percent frequencies are equal to the number of isolates virulent to the $H t$ resistance gene divided by the number of isolates collected in each state.

$\mathrm{b}$ The total number of isolates evaluated for virulence to $H t$ resistance genes across states.

Table 6. Frequency of Exserohilum turcicum isolates of each race found within and across years

\begin{tabular}{|c|c|c|c|c|c|c|c|c|c|}
\hline \multirow[b]{2}{*}{ Race } & \multicolumn{8}{|c|}{ E. turcicum race distribution by year $(\%)$} & \multirow[b]{2}{*}{ Isolates per race $(\%)$} \\
\hline & 1979-1985 & 2007 & 2009 & 2010 & 2011 & 2012 & 2013 & 2014 & \\
\hline 0 & 54 & $\ldots$ & 5 & 14 & 22 & 8 & $\ldots$ & 50 & 20.5 \\
\hline 1 & $\ldots$ & $\ldots$ & 14 & 11 & 46 & 46 & 100 & 33 & 26.9 \\
\hline 12 & $\ldots$ & $\ldots$ & 14 & $\ldots$ & $\ldots$ & $\ldots$ & $\ldots$ & $\ldots$ & 1.9 \\
\hline 13 & $\ldots$ & $\ldots$ & $\ldots$ & 2 & 2 & 8 & $\ldots$ & $\ldots$ & 1.9 \\
\hline 123 & $\ldots$ & $\ldots$ & $\ldots$ & 9 & 2 & $\ldots$ & $\ldots$ & $\ldots$ & 3.2 \\
\hline $123 \mathrm{~m}$ & $\ldots$ & $\ldots$ & 5 & $\ldots$ & 2 & 8 & $\ldots$ & $\ldots$ & 1.9 \\
\hline $12 \mathrm{mn}$ & $\ldots$ & $\ldots$ & $\ldots$ & 2 & $\ldots$ & $\ldots$ & $\ldots$ & $\ldots$ & 0.6 \\
\hline $123 \mathrm{mn}$ & $\ldots$ & $\ldots$ & $\ldots$ & 5 & 2 & $\ldots$ & $\ldots$ & 8 & 2.6 \\
\hline $1 \mathrm{~m}$ & $\ldots$ & $\ldots$ & $\ldots$ & 11 & 6 & 8 & $\ldots$ & 8 & 6.4 \\
\hline $1 \mathrm{mn}$ & $\ldots$ & $\ldots$ & 24 & 23 & 10 & 8 & $\ldots$ & $\ldots$ & 13.5 \\
\hline $1 \mathrm{n}$ & $\ldots$ & $\ldots$ & 14 & 2 & 4 & 15 & $\ldots$ & $\ldots$ & 5.1 \\
\hline 2 & $\ldots$ & $\ldots$ & $\ldots$ & 2 & $\ldots$ & $\ldots$ & $\ldots$ & $\ldots$ & 0.6 \\
\hline 23 & 15 & 50 & 14 & 2 & $\ldots$ & $\ldots$ & $\ldots$ & $\ldots$ & 4.5 \\
\hline $23 \mathrm{~m}$ & 8 & 50 & $\ldots$ & $\ldots$ & $\ldots$ & $\ldots$ & $\ldots$ & $\ldots$ & 1.3 \\
\hline $2 \mathrm{mn}$ & $\ldots$ & $\ldots$ & 5 & $\ldots$ & $\ldots$ & $\ldots$ & $\ldots$ & $\ldots$ & 0.6 \\
\hline $23 \mathrm{mn}$ & 8 & $\ldots$ & $\ldots$ & 5 & $\ldots$ & $\ldots$ & $\ldots$ & $\ldots$ & 1.9 \\
\hline $23 n$ & $\ldots$ & $\ldots$ & $\ldots$ & 2 & $\ldots$ & $\ldots$ & $\ldots$ & $\ldots$ & 1.6 \\
\hline $\mathrm{m}$ & $\ldots$ & $\ldots$ & 5 & 2 & 2 & $\ldots$ & $\ldots$ & $\ldots$ & 1.9 \\
\hline $\mathrm{mn}$ & $\ldots$ & $\ldots$ & $\ldots$ & 5 & $\ldots$ & $\ldots$ & $\ldots$ & $\ldots$ & 1.3 \\
\hline $\mathrm{n}$ & 15 & $\ldots$ & $\ldots$ & 2 & 2 & $\ldots$ & $\ldots$ & $\ldots$ & 2.6 \\
\hline Total no. isolates & 13 & 2 & 21 & 44 & 50 & 13 & 1 & 12 & $156^{\mathrm{a}}$ \\
\hline
\end{tabular}

${ }^{\mathrm{a}}$ The total number of isolates evaluated for race across years. 
for corn production owing to previous selection pressure from corn lines containing these resistance genes for NLB control.

Races with virulence to $H t 1$ were prevalent across major cornproducing regions where isolates were collected after 2007. It is likely, if more isolates were available to test prior to 2009, virulence to $H t 1$ would have been observed. Isolates collected between 1979 and 1985 were arbitrarily selected from part of a collection used for a genetic diversity study by Ferguson and Carson (2004, 2007) in which they observed virulence to Htl across the eastern United States at reduced frequencies than observed in the more recent isolates sampled and screened as a portion of this research. This suggests the frequency of virulence to $\mathrm{Htl}$ has increased in E. turcicum populations; however, a previous study conducted on isolates collected between 1979 and 1981 determined that 72 out of 89 isolates collected in 1981 were virulent to Ht1 (Jordan et al. 1983). The variation between previous studies makes it difficult to determine if the frequency of virulence to $\mathrm{Ht} \mathrm{l}$ has increased, decreased, or remained constant between previously screened populations and the population in this study. Observed variations in population virulence across studies could be affected by sample collection and size. When focusing on the isolates screened in this study, virulence to $H t l$ is present at high frequencies in the current E. turcicum populations across the north central United States, which potentially limits the usefulness of the $\mathrm{Htl}$ gene in breeding for NLB control.

Races virulent to $H t n 1, H t m 1$, or both were fairly prevalent in all states, except Minnesota. Virulence to Htnl was expected given the $H t n 1$ gene may have been previously utilized in breeding programs and virulence had been reported in U.S. E. turcicum populations (Ferguson and Carson 2004; Raymundo and Hooker 1982; Thakur et al. 1989a). The high frequency of virulence to $\mathrm{Html}$ observed in the collection was surprising because there is little evidence available to suggest that the gene has been deployed in breeding programs, and virulence has not been reported previously. Virulence to $\mathrm{Html}$ was found in the isolates collected from North Carolina in 1985; however, the Html gene was not identified until 1993 (Robbins and Warren 1993). The Html resistance response is characterized as reduced disease severity or no disease response, without the telltale chlorosis of $H t 1, H t 2$, and $H t 3$. It is possible the Html gene was unknowingly incorporated into quantitative resistance breeding programs, prior to its identification. Html virulence is common in this E. turcicum isolate collection, but whether that is a response to selection pressure from being deployed unknowingly or if virulence naturally occurs is unclear. The frequency of Html virulence may have been overrepresented in this study.

Races with virulence to $\mathrm{Ht2}, \mathrm{Ht} 3$, or both were the least frequently observed of the isolates tested. Virulence to these $H t$ genes was observed in all years, except 2013, when only one isolate was tested. Despite the presence of virulence across years and in most states, virulent isolates were the least distributed within states. These results are similar to other studies that reported virulence to $\mathrm{Ht} 2$ and $\mathrm{Ht} 3$ to be

Table 7. Frequency of Exserohilum turcicum isolates virulent to the $H t$ resistance genes within and across years

\begin{tabular}{|c|c|c|c|c|c|c|c|}
\hline \multirow[b]{2}{*}{ Race } & \multicolumn{6}{|c|}{ Virulent isolates for each $H t$ gene $(\%)^{\text {a }}$} & \multirow{2}{*}{$\begin{array}{c}\text { No. of isolates per } \\
\text { year }\end{array}$} \\
\hline & Avirulent & Ht1 & $H t 2$ & $H t 3$ & Htm 1 & Htn 1 & \\
\hline 1979-1985 & $54^{\mathrm{a}}$ & 0 & 31 & 31 & 15 & 23 & 13 \\
\hline 2007 & 0 & 0 & 100 & 100 & 50 & 0 & 2 \\
\hline 2009 & 5 & 71 & 38 & 19 & 38 & 43 & 21 \\
\hline 2010 & 14 & 66 & 27 & 25 & 52 & 45 & 44 \\
\hline 2011 & 22 & 74 & 6 & 8 & 22 & 18 & 50 \\
\hline 2012 & 8 & 92 & 8 & 15 & 23 & 23 & 13 \\
\hline 2013 & 0 & 100 & 0 & 0 & 0 & 0 & 1 \\
\hline 2014 & 50 & 50 & 8 & 8 & 17 & 0 & 12 \\
\hline All years & 21 & 64 & 20 & 18 & 32 & 28 & $156^{\mathrm{b}}$ \\
\hline
\end{tabular}

a Percent frequencies are equal to the number of isolates virulent to the $H t$ resistance gene divided by the number of isolates collected in the year.

$\mathrm{b}$ The total number of isolates evaluated for virulence to $H t$ resistance genes across years. present at a low frequency across the United States (Ferguson and Carson 2004; Jordan et al. 1983; Lipps and Hite 1982; Moghaddam and Pataky 1994). The presence of virulence to one of these genes without the presence of the other is confusing because virulence appears to be conferred by the same single gene (Welz 1998). In spite of this, multiple studies have reported races virulent to one gene without virulence to the other gene (Dong et al. 2008; Moghaddam and Pataky 1994; Muiru et al. 2010; Ogliari et al. 2005). However, it is unclear what contributes to the variation in virulent races.

Because nearly all of the commercial corn production in the United States is with hybrids developed by private companies, the degree of $\mathrm{Ht}$ gene deployment is publicly unknown, which makes interpretation of the results more difficult. Most reports have determined present-day commercial breeding programs rarely utilize $H t$ resistance genes for NLB control in the United States owing to the widespread occurrence of virulent races (Ferguson and Carson 2004; Schechert et al. 1999; Welz and Geiger 2000). Ferguson and Carson (2007) indicated that virulence to Ht1 may reduce fitness of E. turcicum, because the mutation was not observed prior to widespread use of the Htl gene. The high frequency of virulence to the Htl gene observed in the isolates screened here could be owing to the continued presence of $\mathrm{Htl}$ in commercial hybrids, or a lack of fitness penalty associated with $\mathrm{Htl}$ virulence. Furthermore, it is difficult to determine if the increase in races and the high frequency of virulence to $\mathrm{Ht}$ genes was owing to current selection pressure, sexual recombination, or random mutation without knowing to what extent $H t$ genes are present.

Qualitative $H t$ resistance genes could be useful in commercial breeding programs. Although the $H t 1$ gene may not provide adequate disease control in most regions owing to widespread virulence, several of the other $\mathrm{Ht}$ genes may be effective across regions. The Ht2 gene and $\mathrm{Ht} 3$ gene would offer the greatest resistance to $\mathrm{E}$. turcicum populations in most regions. Ferguson and Carson (2007) concluded that virulence to $H t 2, H t 3$, and $H t n l$ is not often expressed under field conditions, so hybrids containing these resistance genes may offer control even when virulent populations are present. Virulence to $\mathrm{Html}$ was more widespread than expected, which may limit disease control in the presence of virulent E. turcicum populations; however, little has been reported about virulence under field conditions. Based on the complexity of the E. turcicum population screened in this study, breeding multiple $H t$ resistance genes into lines may not offer as much protection as previous race screening results may suggest. Races conferring virulence to multiple $H t$ genes were diverse and widespread, and several isolates were virulent to all $\mathrm{Ht}$ genes. More $\mathrm{Ht}$ genes have been discovered than were included in this study, and more are likely to be found (Ogliari et al. 2005; Welz and Geiger 2000). Breeding programs could possibly benefit from using additional $\mathrm{Ht}$ genes, as well. Whether or not $\mathrm{Ht}$ genes could help improve long-term control of NLB is hard to predict, but they could offer a level of disease control while quantitative resistance is improved and introgressed into popular corn lines or when paired with quantitative resistant genetics.

\section{Acknowledgments}

Appreciation is given to U. Reuter-Carlson, V. Chapara, K. Krausz, A. McGinnis, D. Pedersen, and E. Miernicki for technical assistance.

\section{Literature Cited}

Berguist, R., and Masias, O. R. 1974. Physiologic specialization in Trichometasphaeria turcicum f. sp. zeae and T. turcicum sp. sorghi in Hawaii. Phytopathology 83: 612-614.

Carson, M. L. 1995. Inheritance of latent period length in maize infected with Exserohilum turcicum. Plant Dis. 79:581-585.

Carson, M. L. 2016. Northern corn leaf blight. Pages 31-33 in: Compendium of Corn Diseases, 4th Ed., G. P. Munkvold, and D. G. White, eds. American Phytopathological Society, St. Paul, MN.

Carson, M. L., and Van Dyke, C. G. 1994. Effect of light and temperature on expression of partial resistance of maize to Exserohilum turcicum. Plant Dis. 78:519-522.

Ceballos, H., and Gracen, V. E. 1989. A dominant inhibitor gen inhibits the expression of $\mathrm{Ht} 2$ against Exserohilum turcicum race 2 in corn inbred lines related to B14. Plant Breed. 102:35-44. 
Dodd, J. L. 1980a. The role of plant stresses in development of corn stalk rot. Plant Dis. 64:533-537.

Dodd, J. L. 1980b. Grain sink size and predisposition of Zea mays to stalk rot. Phytopathology 70:534-535.

Dong, J., Fan, Y., Gui, X., An, X., Ma, J., and Dong, Z. 2008. Geographic distribution and genetic analysis of physiological races of Setosphaeria turcica in northern China. Am. J. Agric. Biol. Sci. 3:389-398.

Ferguson, L. M., and Carson, M. L. 2004. Spatial diversity of Setosphaeria turcica sampled from the eastern United States. Phytopathology 94:892-900.

Ferguson, L. M., and Carson, M. L. 2007. Temporal variation in Setosphaeria turcica between 1974 and 1994 and origin of races 1,23 , and $23 \mathrm{~N}$ in the United States. Phytopathology 97:1501-1511.

Fisher, D. E., Hooker, A. L., Lim, S. M., and Smith, D. R. 1976. Leaf infection and yield loss caused by four Helminthosporium leaf diseases of corn. Phytopathology 66:942-944.

Gevers, H. O. 1975. A new major gene for resistance to Helminthosporium turcicum leaf blight in maize. Plant Dis. Rep. 59:296-299.

Groth, J. V., and Roelfs, A. P. 1987. The concept and measurement of phenotypic diversity in Puccinia graminis on wheat. Phytopathology 77:1395-1399.

Herrmann, A., Löwer, C. F., and Schachtel, G. A. 1999. A new tool for entry and analysis of virulence data for plant pathogens. Plant Pathol. 48:154-158.

Hooker, A. L. 1963. Inheritance of chlorotic-lesion resistance to Helminthosporium turcicum in corn seedlings. Phytopathology 53:909-912.

Hooker, A. L. 1977. A second major gene locus in corn for chlorotic-lesion resistance to Helminthosporium turcicum. Crop Sci. 17:132-135.

Hooker, A. L. 1981. Resistance to Helminthosporium turcicum from Tripsacum floridanum incorporated into corn. Maize Genet. Coop. Newsl. 55:87-88.

Jordan, E. G., Perkins, J. M., Schall, R. A., and Pedersen, W. L. 1983. Occurrence of race 2 of Exserohilum turcicum on corn in the central and eastern United States. Plant Dis. 67:1163-1165.

Leath, S., Thakur, R. P., and Leonard, K. J. 1990. Variation in expression of monogenic resistance in corn to Exserohilum turcicum race 3 under different temperature and light regimes. Phytopathology 80:309-313.

Leonard, K. J. 1993. Durable resistance in the pathosystems: Maize-Northern and southern leaf blights. Pages 99-114 in: Durability of Disease Resistance. T. Jacobs and J. E. Parlevliet, eds. Kluwer Academic Publishers, Dordrecht, Netherlands.

Leonard, K. J., Levy, Y., and Smith, D. R. 1989. Proposed nomenclature for pathogenic races of Exserohilum turcicum on corn. Plant Dis. 73:776-777.

Levy, Y., and Cohen, Y. 1983. Biotic and environmental factors affecting infection of sweet corn with Exserohilum turcicum. Phytopathology 73:722-725.

Lipps, P. E., and Hite, R. E. 1982. Exserohilum turcicum virulent on corn with the $H t$ resistance gene in Ohio. Plant Dis. 66:397-398.

Lipps, P. E., Pratt, R. C., and Hakiza, J. J. 1997. Interactions of $H t$ and partial resistance to Exserohilum turcicum in maize. Plant Dis. 81:277-282.

Mallowa, S. O., Esker, P. D., Paul, P. A., Bradley, C. A., Chapara, V. R., Conley, S. P., and Robertson, A. E. 2015. Effect of maize hybrid and foliar fungicides on yield under low foliar disease severity conditions. Phytopathology 105:1080-1089.

Moghaddam, P. F., and Pataky, J. K. 1994. Reactions of isolates from mating of races 1 and 23N of Exserohilum turcicum. Plant Dis. 78:767-771.

Mueller, D. S., Wise, K. A., Sisson, A. J., Allen, T. W., Bergstrom, G. C., Bosley, B., Bradley, C. A., Byamukama, E., Chilvers, M. I., Collins, A., Faske, T., Friskop, A. J., Hollier, C. A., Isakeit, T., Jackson-Ziems, T. A., Jardine, D. J., Kinzer, K., Koenning, S. R., Malvick, D. K., Meyer, R. F., McMullen, M., Mostrom, M. S., Paul, P., Robertson, A. E., Roth, G. W., Smith, D. L.,
Tande, C. A., Tenuta, A., and Vincelli, P. 2016. Corn yield loss estimates due to diseases in the United States and Ontario, Canada from 2012 to 2015. Plant Health Prog. Online publication. doi.org/10.1094/PHP-RS-16-0030.

Muiru, W. M., Koopmann, B., Tiedemann, A. V., Mutitu, E. W., and Kimenju, J. W. 2010. Race typing and evaluation of aggressiveness of Exserohilum turcicum isolates of Kenya, German and Austrian origin. World J. Agric. Sci. 6:277-284.

Munkvold, G. P., Doerge, T., and Bradley, C. A. 2008. IPM is still alive for corn leaf diseases: Look before you spray. In: Proc. 62nd Annu. Corn Sorghum Res. Conf. Chicago. CD-ROM, American Seed Trade Association, Alexandria, VA.

Ogliari, J., Guimaraes, M., Geraldi, I., and Camargo, L. 2005. New resistance genes in the Zea mays-Exserohilum turcicum pathosystem. Genet. Mol. Biol. 28:435-439.

Pataky, J. K., Perkins, J. M., and Leath, S. 1986. Effects of qualitative and quantitative resistance on the development and spread of northern leaf blight of maize caused by Exserohilum turcicum races 1 and 2. Phytopathology 76 : 1349-1352.

Pedersen, W. L., and Oldham, M. G. 1992. Effect of three tillage practices on development of northern corn leaf blight (Exserohilum turcicum) under continuous corn. Plant Dis. 76:1161-1164.

Raymundo, A. D., and Hooker, A. L. 1981. Measuring the relationship between northern corn leaf blight and yield losses. Plant Dis. 65:325-327.

Raymundo, A. D., and Hooker, A. L. 1982. Single and combined effects of monogenic and polygenic resistance on certain components of northern corn leaf blight development. Phytopathology 72:99-103.

Robbins, W. A., and Warren, H. L. 1993. Inheritance of resistance to Exserohilum turcicum in PI 209135 'Mayorbela' variety of maize. Maydica 38:209-213.

Schechert, A. W., Welz, H. G., and Geiger, H. H. 1999. QTL for resistance to Setosphaeria turcica in tropical African maize. Crop Sci. 39:514-523.

Simcox, K. D., and Bennetzen, J. L. 1993a. Mapping the HtN resistance gene to the long arm of chromosome 8. Maize Genet. Coop. Newsl. 67:118-119.

Simcox, K. D., and Bennetzen, J. L. 1993b. The use of molecular markers to study Setosphaeria turcica resistance in maize. Phytopathology 83:1326-1330.

Simcox, K. D., Pedersen, W. L., and Nickrent, D. L. 1993. Isozyme diversity in Setosphaeria turcica. Can. J. Plant Pathol. 15:91-96.

Thakur, R. P., Leonard, K. J., and Jones, R. K. 1989a. Characterization of a new race of Exserohilum turcicum virulent on corn with resistance gene $\mathrm{HtN}$ Plant Dis. 73:151-155.

Thakur, R. P., Leonard, K. J., and Leath, S. 1989b. Effects of temperature and light on virulence of Exserohilum turcicum on corn. Phytopathology 79:631-635.

Tuite, J. 1969. Plant Pathological Methods. Burgess Publishing, Minneapolis, MN

Turner, M. T., and Johnson, E. R. 1980. Race of Helminthosporium turcicum not controlled by $\mathrm{Ht}$ genetic resistance in corn in the American corn belt. Plant Dis. 64:216-217.

Ullstrup, A. J., and Miles, S. R. 1957. The effects of some leaf blights of corn on grain yield. Phytopathology 47:331-336.

Welz, H. G. 1998. Genetics and epidemiology of the pathosystem Zea mays/ Setosphaeria turcica. Habilitation thesis, University of Hohenheim, Stuttgart, Germany.

Welz, H. G., and Geiger, H. H. 2000. Genes for resistance to northern corn leaf blight in diverse maize populations. Plant Breed. 119:1-14.

Windes, J. M., and Pedersen, W. L. 1991. An isolate of Exserohilum turcicum virulent on maize inbreds with resistance gene $H t N$. Plant Dis. 75:430E

Wise, K., and Mueller, D. 2011. Are fungicides no longer just for fungi? An analysis of foliar fungicide use in corn. APSnet. 